\title{
The China Development Bank and Sustainable Development
}

\author{
V. Levanchuk
}

Valentina Levanchuk - Economist; 27 - 79 Nakhimovsky prospect, 117209 Moscow, Russian Federation; E-mail: val.levanchuk@gmail.com

In this article, the author presents an empirical study of sustainable banking in China, and examines the flagship China Development Bank (CDB). The CDB is directly supervised by the State Council of the People's Republic of China and is one of the largest state-owned financial institutions in the country. Its overseas lending is growing rapidly and it increasingly acts as a global player, influenced by a variety of international actors. Using the mercantilist framework, the author investigates how the CDB's social policies diverge from those set by the Chinese authorities. The analysis discusses the CDB's policy variations that are not in line with government interests or prescribed directly by governmental bodies. It concludes that the bank has been active in developing and establishing its own corporate strategy for implementing the concept of sustainable development, to promote balanced development of the economy, society and the environment. That strategy contains the norms and rules set by Chinese regulatory agencies with regard to social and environmental areas, as well as important elements of international practice of corporate responsibility and sustainable funding. The CDB is most likely driven by its desire to be considered internationally as a good corporate citizen, and often acts independently from governmental guidance, which in some ways undermines mercantilist perceptions. ${ }^{1}$

Key words: Sustainable development, China Development Bank, corporate social responsibility, environmental policy, global political economy, mercantilism

\section{Assessing the CDB's environmental and social policies}

China has undergone outstanding economic growth over the past 30 years and has become the world's second largest single-country economy [Zhang, 2012, p. 2]. Many researchers and international institutions have regarded this astonishing rise in economic might as the "China miracle" (Ibid., p. 4). However, this pro-growth course has not only boosted the Chinese economy, but created a great number of social and environmental problems. Population growth, rapid urbanization, a leap in consumption rates, and intense resource exploitation have put formidable pressure on China's resources and environment.

At this time when Chinese government policy-makers have been exploring new approaches to combining economic growth and sustainable development, the Deputy Chief of the Supervisory Board Office of the China Development Bank, Hu Bin, launched his presentation of the bank's policy towards sustainability and a green economy at the International Forum on Green Growth, held in Venice on 26-27 November 2012. The forum report [Bin, 2013] observes that the CDB has been taking pains to integrate environmental and social factors in its strategy and performance.

${ }^{1}$ The article was submitted to the editors in January 2016. 
In this respect, analysis of the purposes of Chinese sustainable banking and its core player, the China Development Bank, becomes overwhelmingly important. It is both timely and worthwhile given the rapid growth of overseas lending of the CDB and an increasing expectation from national and international civil society groups that the bank will pay more attention social and environmental issues within investment decision-making. As the CDB rapidly evolves, and is more concerned with adapting modern international practices into its development model, the question arises as to whether its policies on sustainability reflect its own interests or solely the interests of the Chinese government, and whether their policies actually differ.

Hence, the research question can be outlined as follows: To what extent is the China Development Bank independent from the government in determining its environmental and social policies? In this study, environmental and social policies stand for a range of tools - standards, guidelines, safeguards, and regulations - aimed at enhancing the environmental and social performance of the bank.

From all the theoretical diversity of the Global Political Economy field, a mercantilist perspective is derived to provide both a powerful and plausible answer to the posed research question. In particular, this study will rely on the Listian comprehension of state policy and his present-day followers' understanding of state strategies. List's National System of Political Economy, published in 1841, put forward a dynamic approach to economic development with only the state being capable of harnessing the productive power of national industries [List, 1856, p. 208]. Similarly, in neo-Listian political economy the role of the state is central in stimulating economic development [Wade, 2004; Amsden, 2007; Chang, 2002, 2005]. Based on their analysis, Chang and Grabel [2004] describe models in which state-owned enterprises and banks play a modest role of governmental policy conductors. Either way, Kohli [2004] argues that the "effective state" intensively coordinates the banking sector in order to cultivate globally competitive firms. Not surprisingly, neo-Listians advocate that China has not only grasped that mercantilism is a good friend, but has been the leading bearer of the mercantilist torch [Rodrik, 2013]. Its economic miracle has been conceptualised by writers operating within the Listian framework as the product of active governmental efforts to stimulate industrial production, with financial enterprises being responsive agents of the state's priorities and objectives [Rodrik, 2013]. Consequently, the mercantilists' account is expected to postulate that the CDB is just an instrument of the Chinese government to reach its objectives; it has no voice and therefore its environment and social policies do not differ from those of the Chinese government.

Accordingly, a hypothesisbased on the mercantilist assumption can be formulated in the following way: If the $C D B$ is a tool for pursuing the interests of the Chinese government, then the environmental and social policies of the $C D B$ are not expected to differ from those of the Chinese government. Drawing on the hypothesis and the mercantilist theoretical assumption, the Chinese government's interests are assumed to be an independent variable, whereas the CDB's environmental and social standards play the role of a dependent variable.

\section{The Chinese government's environmental and social regulations for the banking sector}

The China Development Bank's environmental guidelines should be considered in the context of rapidly evolving regulations for greening China's banking sector. This sector is recognized as playing a crucial role in thedevelopment of a sustainable and environmentally friendly economy [Leung and Zhao, 2013, p. 20]. Apart from common green policies, such as green tax or green procurement, China has in recent years introduced a series of green policies specifically for banks, most importantly the green credit policy [Aizawa \& Yang, 2010, p. 119]. 
In July 2007, the People's Bank of China (PBoC), the Ministry of Environmental Protection (MEP) and the China Banking Regulatory Commission (CBRC) launched a green credit policy, which is perhaps the best-known, best-developed economic policy, and the most advanced mechanism of executing enterprises' corporate environmental and social responsibility in China [Aizawa \& Yang, 2010, p. 125]. The aim of this policy is to move loan financing away from environmentally hazardous enterprises and projects toward enterprises that further resource conservation, energy efficiency and pollution reduction [Xiaogang et al, 2011, p. 46]. It has three major elements: i) enhancing banks' management of environmental performance; ii) sharing environmental information between the environmental authority and the financial sector; and iii) imposing responsibility on banks for violation of the policy (Ibid.). Thus, banks are prohibited to provide loans to highly polluting and energy inefficient enterprises, which fail environmental impact assessments (EIAs) and inspections.

The response from the financial sector came in the form of Guidelines on Corporate Social Responsibility (CSR) for Banking Financial Institutions in China, issued by the China Banking Association (CBA) in January 2009 [KPMG, 2009]. The goal of the guidelines is to urge banking institutions to promote sustainable development and a harmonious economy, society, and environment through the implementation of social corporate responsibility [Ibid.]. The guidelines set out requirements for environmental responsibility, namely research and analysis of the Equator Principles, advocacy of independent EIA through site survey and review, environmental protection training for staff and clients to include EIA procedures, and setting up a specialized department for resource conservation and environmental protection [Xiaogang et al., 2011, p. 48]. In February 2012 the CBRC released the Green Credit Directive, containing seven chapters of 30 provisions for Chinese policy banks as well as commercial and cooperative banks on green credit policies, capacity building, monitoring and supervision, and information disclosure. They provide directions for green lending policies and oblige banks to "identify, measure, monitor, and control environmental and social risks" in their operations [CBRC, 2012].

In February this year, the Ministry of Commerce and Environmental Protection released guidelines on environmental protection for overseas investments of Chinese banks. The new policy embodies basic guidance for Chinese banks and companies on how to manage environmental and local community risks when operating abroad [Ministry of Commerce and the Ministry of Environmental Protection, 2013]. The policy requires banks and companies to set up a series of environmental safeguards by organizing environmental impact assessments, providing access to pollution results for the public, and respecting the beliefs and rights of local communities [Ibid.]. While some experts (Katherine Lu, interview) are sceptical about the adequacy of the policy to fully regulate and control Chinese banks and companies abroad, the policy is the first to draw attention to the importance of environmental protection of China's increasing overseas investment and production activities. As an indication of China's concerted efforts to incorporate sustainability into the activities of the banking sector, Ye Yanfei, Deputy Director General of the Statistics Department at the CBRC, stated in an interview that "green policies are essential for sustainable growth and in this regard the financial sector can be the catalyst in driving responsible practices and strategies for the companies it lends to" [IFC, 2012].

\section{CDB' environmental and social policies}

The China Development Bank (CDB) is one of the major financial institutions in the People's Republic of China. It was established in 1993 as one of the three Chinese policy banks ${ }^{2}$ to ad-

${ }^{2}$ Together with the Export-Import Bank of China (China Eximbank) and the Agricultural Bank of China, see [Provaggi, 2013]. 
Table 1. Major environmental and social guidelines of regulatory agencies for Chinese banks

\begin{tabular}{|l|l|}
\hline \multicolumn{1}{|c|}{ Regulations } & When Adopted \\
\hline State Council & \\
\hline Law on Environmental Protection (Provisional) & 1979 \\
\hline Law on Environmental Protection of the People's Republic of China & 1989 \\
\hline Environmental Impact Assessment Law of the People's Republic of China & September 2003 \\
\hline Ministry of Commerce & 2005 \\
\hline Provisions on the Authorization of Investment to Run Business Abroad & August 2007 \\
\hline $\begin{array}{l}\text { Guidelines on Sustainable Building of Overseas Forests by Chinese Companies } \\
\text { (with State Forestry Bureau) }\end{array}$ & March 2009 \\
\hline $\begin{array}{l}\text { Guidelines on Sustainable Management and Utilization of Overseas Forests by Chinese } \\
\text { Companies (with State Forestry Bureau) }\end{array}$ & February 2013 \\
\hline $\begin{array}{l}\text { Guidelines on Environmental Protection for Overseas Investments (with Ministry of } \\
\text { Environmental Protection) }\end{array}$ & November 2007 \\
\hline China Banking Regulatory Commission & July 2007 \\
\hline $\begin{array}{l}\text { Opinion on Strengthening the Corporate Social Responsibility } \\
\text { of Banking Institutions }\end{array}$ & February2012 \\
\hline Green Credit Guidelines & \\
\hline Green Credit Directive &
\end{tabular}

Sources: [China Sustainable Finance Newsletter, 2013; KPMG, 2009; Aizawa \& Yang, 2010; Gallagher et al., 2013].

vocate projects in line with national policy objectives (CDB, "Domestic Financing"). It has been at the center of China's infrastructural development and financed coal, electricity, oil, transportation, agriculture, water resources, public infrastructure and other large-scale projects, such as the three Gorges Dam and the Beijing Olympic Games venues (CDB, "Strategic Focus"). The Bank is directly subordinate to the jurisdiction of China's highest governing body, the State Council, which has full ownership and implicitly guarantees the Bank's debt (CDB, "Funding Sources"). The CDB is reported to be the largest development bank in the world by total assets and has earned a reputation as a key player in China's "going out" strategy [Geoff, Anderlini and Sender, 2011]. It has put significant effort into expanding overseas in recent years, having increased its outstanding foreign currency loans more than sevenfold in the past five years [BankTrack, Friends of the Earth, 2012, p. 7].

While the Bank fully supports the macroeconomic infrastructural development policies of the central government, there is at the same time growing evidence that it increasingly follows a highly commercial and profit-driven strategy [Downs, 2011]. This approach was first introduced by Chen Yuan, the man at the helm of the organization, who depoliticized the Bank by separating risk assessment personnel from those in charge of loan approval [Provaggi, 2013, p. 2]. Since then, the Bank has benefited from the government's sovereign rating, which keeps funding costs relatively low; on the other hand, it has a very bargain-based vision of becoming a fully commercial institution and raising money at its own credit rate [Ibid., p. 5]. In April $2013 \mathrm{Mr}$ Chen stepped down as Chairman to set up the emerging BRICS Development Bank. 
The appointment of $\mathrm{Hu}$ Huaibang, former head of the Bank of Communication, might further accelerate the commercialization and "secession" of the CDB despite the government's unwillingness to jeopardize the CDB's role as its primary performer for strategic development projects [Provaggi, 2013, p. 6]. Many argue that the Bank is at the stage of finding a new clear identity, since the double policy of balancing between profitability, global expansion of portfolio and compliance with the State Council's goals is becoming difficult to manage (Katherine Lu, interview).

The CDB's orientation towards greater independence from the government is also reflected in its self-supporting steps to fulfill social and environmental responsibilities. The Bank defines its mission as providing "medium- to long-term financing facilities that assist in the development of a robust economy and a healthy, prosperous community" [CDB, CSR, 2014]. It has published a summary of its policies and actively participates in initiatives on refining its environmental and social performance at home and abroad [BankTrack, Friends of the Earth, 2012, p. 4].

\section{CDB domestic initiatives}

In line with its ambition to become a world-class lender (CDB "Mission"), the Bank publicly disclosed a summary of its environmental policies in its bond prospectus as early as 2005. In order to further increase the transparency of its operations, the Bank released its first corporate social responsibility report in 2007, ahead of the China Banking Association, which issued guidelines for banks' corporate social responsibility reports two years later, in 2009. In the following years, it included information about its environmental policies and management in its annual reports, CSR reports and on the website [BankTrack, Friends of the Earth, 2012, p. 16]. In accordance with international best practice, the CDB's reports are also verified by a thirdparty auditor. In 2010 this was done by Pricewaterhouse Coopers [BankTrack, Friends of the Earth, 2012, p. 22].

When the government prohibited the provision of loans for highly polluting and energyintensive projects in 2007, the CDB in turn issued its own policies to promulgate the environmental maintenance of its lending practices [CDB, 2007], including:

- Guidelines of CDB in Developing and Evaluating Environmental Protection Projects;

- Guidelines on Environmental Protection Project Development Review;

- Guidelines of CDB on Special Loans for Energy-saving and Emission-reducing Businesses;

- Guidelineson Solar Power Development;

- Working Plan of CDB for Loans to Reduce Pollution and Emissions.

Of these five, the most important for the CDB are "Guidelines on Environmental Protection Project Development Review" [Gallagher et al., 2013, p. 9]. They focus on client suitability review, ex-ante environmental impact assessment, and ex-post environmental monitoring. The general procedure is as follows: first, the CDB carries out a client suitability review by assessing the environmental record of the companies requesting a loan. Then the CDB conducts an exante EIA review to make sure that resource and environmental protection costs are included in the project's operational costs. Once the project is completed, the CDB also conducts ex-post environmental monitoring. This monitoring incorporates consultations with environmental agencies on whether the project has been implemented using methods that meet the requirements of environmental protection (see Table 2). 
Table 2. CDB guidelines on environmental protection of project development

\begin{tabular}{|l|l|}
\hline Loan Cycle & \multicolumn{1}{|c|}{ Guidance } \\
\hline Pre-lending & $\begin{array}{l}\text { Clients must be in compliance with all environmental laws of the People's Republic of } \\
\text { China; } \\
\text { All loan applications require an environmental impact assessment (EIA); } \\
\text { For highly polluting and energy-intensive industries such as coal mining, oil and gas } \\
\text { exploration and development, power generation and transmission, hydropower, etc., EIAs } \\
\text { must be approved by relevant environmental authorities; } \\
\text { EIAs must be completed by an independent evaluator; } \\
\text { Environmental standards and costs can be written into loan covenants in order to commit } \\
\text { borrowers to environmental promises; } \\
\text { The Bank can exercise the "one-ballot veto" procedure which allows loans to be rejected } \\
\text { by the credit committee solely for environmental reasons; } \\
\text { The Bank assigns two personnel to conduct due diligence for each loan application: one to } \\
\text { evaluate the loan and the other to evaluate the client; } \\
\text { The Bank has an appraisal department to assess environmental and social risks, and also } \\
\text { manages environmental and social issues across business units }\end{array}$ \\
\hline Post-lending & $\begin{array}{l}\text { In order for loan requirements to be considered fulfilled, clients must provide proof from } \\
\text { a relevant environmental department that the project meets environmental protection } \\
\text { requirements }\end{array}$ \\
\hline
\end{tabular}

Source: [BankTrack, Friends of the Earth, 2012, p. 17; CDB 2007, 2008, and 2009 Social Responsibility reports].

The CDB has initiated the establishment of a number of other green policies and initiatives. For instance, in cooperation with the Ministry of Environmental Protection the CDB has worked on a research project to elaborate environmental and social performance assessment methods that could be used to evaluate bank loans [CDB, 2010, CSR report, p. 50]. In the "Development Finance Cooperation Agreement" with the MEP, the CDB emphasizes renewable energy, energy efficiency, and environmental protection as its priority lending spheres [MEP 2014]. It has also been involved in the project of the Chinese Academy of Sciences and the World Wildlife Fund on the protection of the Yangtze River, which analyzed the impact of climate change and large-scale construction on the ecology of the river and advised on policy solutions [BankTrack, Friends of the Earth, 2012, p. 19].

\section{CDB engagement with international policies}

The CDB has been actively working with international organizations to improve its environmental and social policies. For example, together with the World Bank, the CDB set up an "Environmental Impact Assessment Framework for Lending to Small or Medium-Sized Enterprises (SMEs)." Seeking to expand abroad, in 2010 CDB further extended its environmental framework by creating 142 performance indicators based on the United Nations Global Compact's 10 principles on human rights, the environment, labor and corruption. It has also indicated efforts to enhance public participation systems in its post-lending management, which surpass the bounds of the Chinese government's regulations [CDB, 2010, CSR report, p. 50]. In addition, the $\mathrm{CDB}$ is seriously considering the adoption of the Equator Principle, which would further enhance its social and environmental practices (Katherine Lu, interview).

The CDB has also engaged in a series of international activities on the prevention and management of environmental and social risks. For example, it sent a delegation on a study tour arranged by the United Nations Environment Programme-Finance Initiative (UNEP-FI) to 
learn about corporate social responsibility and sustainable finance. It studied the Global Reporting Initiative (GRI) corporate resposibility reporting standard and has been active in promoting its use in China by sponsoring GRI workshops. Finally, it has participated in the United Nations Global Compact since 2006, issued its first CSR report according to UNGC guidelines in 2008, and developed guidelines for responsible investing in conflict areas in 2009-2011 [BankTrack, Friends of the Earth, 2012, p. 20]. The Bank's participation in initiatives of this kind is in line with the development of its standards and practices.

Gallagner et al performed a comparative analysis on the official guidelines of the CDB and its major competitor in international development finance, the World Bank, to examine the degree to which the CDB has incorporated common social and environmental guidelines into its current lending practices. As the table shows, the CDB currently incorporates four of nine common social and environmental guidelines. These are environmental impact assessment, project review, public consultations with communities affected by the project, and ex-post environmental impact assessment. Although the CDB still needs to catch up with the World Bank by adopting six other widely-accepted social and environmental policies, it surpasses the World Bank in that it requires ex-post Environmental Impact Assessment. This requirement is reported to be a significant improvement on other major international financial institutions, such as International Finance Corporation (IFC) and Inter-American Development Bank (IADB); it establishes a formal review process on the project's overall impact on the local community and environment with an examination of potential follow-up corrective action [Gallagher et al., 2013, p. 12]. Furthermore, the CDB is a young player in the development lending industry, and its adoption of common social and environmental policies is relatively new, beginning approximately five years ago. Comparing the CDB's performance in this direction with the World Bank in the 1980s, it is ahead of history, starting to adhere to such practices much earlier [Gallagher et al., 2013, p. 14].

Table 3. Comparative Analysis of the CDB and the World Bank regarding common environmental and social policies

\begin{tabular}{|l|c|c|}
\hline \multicolumn{1}{|c|}{ Environmental Guidelines } & World Bank & $\begin{array}{c}\text { China Development } \\
\text { Bank (CDB) }\end{array}$ \\
\hline Ex-ante Environmental Impact Assessment & $\mathrm{X}$ & $\mathrm{X}$ \\
\hline Project Review of Environmental Impact Assessment & $\mathrm{X}$ & $\mathrm{X}$ \\
\hline Industry-Specific Social and Environmental Standards & $\mathrm{X}$ & $\mathrm{X}^{*}$ \\
\hline $\begin{array}{l}\text { Ensure Compliance with Host Country's Environmental Laws and } \\
\text { Regulations }\end{array}$ & $\mathrm{X}$ & \\
\hline International Environmental Laws and Regulations & $\mathrm{X}$ & \\
\hline Public Consultations with Communities Affected by the Project & $\mathrm{X}$ & \\
\hline Grievance Mechanism & $\mathrm{X}$ & $\mathrm{X}$ \\
\hline Independent Monitoring and Review & $\mathrm{X}$ & $\mathrm{X}$ \\
\hline Establishing Covenants linked to Compliance & & \\
\hline Ex-post Environmental Impact Assessment & & \\
\hline
\end{tabular}

*The CDB requires that if the host country's environmental standards are inadequate, the firm follows Chinese standards or international best practice.

Source: [Gallagher et al., 2013, p. 12]. 
Clearly, the CDB's environmental and social policies go above and beyond the scope of applicable banking sector laws. This might be motivated by the Bank's desire to strengthen its competitiveness through an enhanced global corporate reputation, as well as to rule out any harm to its financial returns in light of its growing independence from the government. Companies that fail to improve their environmental and social governance can reduce their market value and long-term performance [UNEP Finance Initiative, 2004]. A report by the United Nations Global Compact Initiativefound that sound environmental and social governance is a prerequisite for a company's success on the global market. It argues that commitment to addressing environmentaland social issues has a positive impact on corporate financial performance, the cost of capital, and reputation [The Global Compact, 2004]. The CDB increasingly interacts on a global scale, enters foreign stock exchanges, and markets its financial products abroad. Therefore, it takes new levels of interest in environmental and social responsibility, and its recent and rapid development indicates a growing awareness of the need for transparency and disclosure. It adopts global standards for environmentally and socially responsible project finance.

As one of the most influencial banks in the world [Sanderson \& Forsythe, 2013], the CDB's environmental and social policies can set a precedent for other banks and financial corporations in China. As Michelle Chan, Director of Economic Policy Programs at Friends of the Earth US, stated: “CDB's concerted efforts to finance environmentally beneficial activities shows that the bank has tremendous potential to catalyze ecologically and socially sustainable development. By working hand-in-hand with stakeholders, including Chinese civil society, CDB has the potential to show global leadership in this area" [BankTrack, 2012].

\section{Conclusion}

Regulations for the banking sector show the intention of the Chinese government to tackle the problem of sustainable development from a financial perspective. However, the study finds that the CDB's social and environmental policies go beyond the regulations of the Chinese government. Although the CDB operates under the direct control of the government, it seems to be more active than is required by the government on the issue of sustainability. The Bank incorporates best international practice and engineers its own policies, which could prove groundbreaking for the Chinese banking sector. Thus, on the one hand, the government allows and encourages the efforts towards sustainability taken by the CDB, and the Bank does not yet pursue a totally independent policy in the field. On the other hand, the CDB is not a passive and voiceless instrument of the government, accepting and following solely governmental regulations. On the contrary, it is an innovator which instructs the government on certain policies and issues of sustainability, with the government's consent. Therefore, the hypothesis based on the mercantilist assumption about the full dependency of the CDB's social and environmental policies from those of the government can be refuted, because the dependency exists, but it is far from absolute. Mercantilist theory proves to be right in its notion of strong governmental control under which the bank functions. But the growing independence of the bank might in the near future present a serious empirical challenge to this assumption. Moreover, the influence of international and national civil society groups, which a mercantilist would assume to be rather weak, cannot be underestimated so readily, especially with regard to sustainable development. Further research is needed to analyze the processes and results of the CDB's and government's interactions concerning policies of sustainability. 


\section{References}

Amsden A. (2007) Escape from Empire: The Developing World's Journey Through Haven and Hell. Cambridge: MIT Press.

Aizawa M. and Yang C. (2010) Green Credit, Green Stimulus, Green Revolution? China's Mobilization of Banks for Environmental Clenup. The Journal of Environment and Development, no 19(2), pp. 119-144.

Bin H. (2013) The Role of Financial Institutions in Promoting a Green Economy: China Development Bank. Review of Environment, Energy and Economics(Re3). Available at:http://dx.doi.org/10.7711/feemre3.2013.04.001 (accessed 8 December 2015).

Boyle C. (2008) The Mystery of Modern Wealth: Mercantilism, Value, and the Social Foundations of Liberal International Order. European Journal of International Relations, 14 (3), 405-429.

Chang H.-J. (2005) The East Asian Development Experience: The Miracle, the Crisis, and the Future. London: Third World Network and Zed Press.

Chang H-J. and Grabel I. (2004) Reclaiming Development - an Alternative Economic Policy Manual. London: Zed Press.

Downs E. (2011) Inside China, Inc: China Development Bank's Cross-Border Energy Deals. Brookings Intitution.

Gallagher K., Koleski K., Irwinet A. (2013) Chinese Finance in Latin America: Brown or Green? TEMTI Series of Economic Perspectives on Global Sustainability.

Geoff D., Anderlini J. and Sender H. (2011) China's lending hits new heights. Financial Times, 17 January.

Kirshner J. (2009). Realist Political Economy. Traditional Themes and Contemporary Challenges/ Handbook of International Political Economy (IPE). IPE as a global conversation (ed. M. Blyth), pp. 36-47. New York: Routledge.

Kohli A. (2004) State-directed Development: Political Power and Industrialization in the Global Periphery. Cambridge: Cambridge University Press.

KPMG (2009) China boardroom update. CBA Guidelines on Corporate Social Responsibility. Available at: https:// www.kpmg.com/CN/en/IssuesAndInsights/ArticlesPublications/Newsletters/China-boardroom-update/ Documents/China-boardroom-update-0904-05.pdf (accessed 8 December 2015).

Leung D. and Zhao Y. (2013) Environmental and Social Policies in Overseas Investments: Progress and Challenges for China. Washington: World Resources Institute. Available at: http://www.wri.org/publication/environmentaland-social-policies-in-overseas-investments-progress-and-challenges-for-china (accessed 8 December 2015).

List F. (1856) National System of Political Economy. Philadelphia PA: J.B Lippencott, republished by University of Michigan.

List F. (1909) Outlines of American Political Economy/Hirst M. Life of Friedrich List and Selections from his Writings, pp. 147-272. London: Smith, Elder \& Co.

Morgenthau J. (1948) Politics Among Nations. The Struggle for Power and Peace. New York: Alfred A. Knopf.

Provaggi A. (2013) China Development Bank's Financial Mechanisms: Focus on Foreign Investments. Global Projects Center. Stanford University. Available at: https://gpc.stanford.edu/sites/default/files/uc07_0.pdf (accessed 8 December 2015).

Rodrik D. (2013) The New Mercantilist Challenge. Project Syndicate, 9 January. Available at: http://www. project-syndicate.org/commentary/the-return-of-mercantilism-by-dani-rodrik\#JQXVFeKSmD8HaYHu.99 (accessed 8 December 2015).

Sanderson H., Forsythe M. (2013) China's Superbank. Singapore: Bloomberg.

Wade R. (2004 ). Governing the Market. Princeton: Princeton University Press.

Xiaogang Y. (ed.) (2011) Environmental Report on Chinese Banks. BankTrack. Available at: http://www.euchina.net/upload/pdf/materialien/Yunnan-2011-environmental_records_of_chinese_banks_2010_eng_1107-07.pdf (accessed 8 December 2015).

Zhang J. (2012) Delivering Environmentally Sustainable Economic Growth: The Case of China. University of California, San Diego: Asia Society. Available at: http://asiasociety.org/files/pdf/Delivering_Environmentally_ Sustainable_Economic_Growth_Case_China.pdf (accessed 8 December 2015). 